\title{
PROPEPTIDUL AMINO-TERMINAL AL PROCOLAGENULUI TIP I LA PACIENŢII CU DEFICIT DE HORMON DE CREŞTERE ÎN PERIOADA DE TRANZIȚIE
}

\author{
Mariana Costache-Outas ${ }^{1,2}$, Andra Caragheorgheopol ${ }^{3}$, Camelia Procopiuc ${ }^{3}$, \\ Cristina Dumitrescu ${ }^{3}$, Cosmina Raluca Costache ${ }^{4}$, Simona Fica ${ }^{1,5}$ \\ ${ }^{1}$ Universitatea de Medicină şi Farmacie „, Carol Davila“", Bucureşti \\ ${ }^{2}$ Spitalul Clinic ,COlțea“, București \\ ${ }^{3}$ Institutul Naţional de Endocrinologie „, C.I. Parhon “, Bucureşti \\ ${ }^{4}$ Spitalul Clinic „,Dr. Ioan Cantacuzino“, Bucureşti \\ ${ }^{5}$ Spitalul Universitar de Urgență ,Elias “, Bucureşti
}

\begin{abstract}
REZUMAT
Introducere. Achiziția de masă osoasă continuă şi după atingerea taliei finale în perioada de tranziție. Deficitul de hormon de creştere (GHD) pare să aibă un efect semnificativ asupra turnover-ului colagenului în timpul copilăriei şi mai puțin în timpul maturității. Propeptidul amino terminal al colagenului tip I (P1NP) este un marker de formare osoasă cu variabilitate intraindividuală scăzută fată de IGF1.

Subiecți şi metodă. 17 pacienți de sex masculin diagnosticați în timpul copilăriei cu GHD, retestați în perioada de tranziție, au fost evaluați la minimum 3 luni de la întreruperea tratamentului cu GH. Am evaluat corelația P1NP cu IGF1. Am determinat puterea predictivă a P1NP în identificarea pacienților cu deficit de GH persistent. Rezultate. Am găsit o corelație pozitivă puternică între P1NP şi IGF-1 în grupul de pacienți care au menținut deficitul de $\mathrm{GH}$ în perioada de adult tânăr $(r=0,72, \mathrm{Cl}[0,02$ la 0,94$], p=0,046)$. O valoare prag pentru P1NP de - 0,66 SDS prezice persistența deficitului de GH cu o sensibilitate de $62,5 \% \mathrm{Cl}[24,5$ la 91,5], specificitate de $75 \%$ Cl [47,6 la 92,7] şi AUC = 0,719 Cl [0,5 la 0,881], p<0,05. Nu am găsit o diferență semnificativă atunci când am comparat AUC pentru cei 2 parametri $(p=0.29)$.

Concluzii. În perioada de tranziție, atunci când viteza de creştere nu mai este disponibilă, dinamica P1NP în timpul terapiei substitutive cu GH ar putea fi utilă în cuantificarea eficienței tratamentului.
\end{abstract}

Cuvinte cheie: Markeri de colagen, P1NP, IGF1, hormon de creştere, deficit de GH, perioada de tranziție

\section{Mulțumiri}

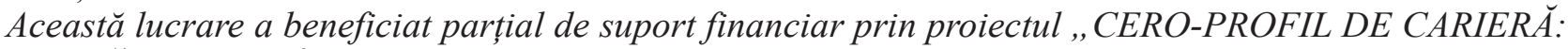
CERCETĂTOR ROMÂN“ contract nr. POSDRU/159/1.5/S/135760, cofinanțat din Fondul Social European prin Programul Operațional Sectorial Dezvoltarea Resurselor Umane 2007-2013.

\section{INTRODUCERE}

Achiziția de masă osoasă continuă şi după atingerea înălțimii finale, în cursul perioadei de tranzitie, care este definită ca intervalul de timp parcurs de la atingerea înălțimii finale şi până la finalizarea dezvoltării somatice. Axa hormon de creştere $(\mathrm{GH}$, growth hormone) - factor de creştere, similar insulinei I (IGF1, insulin growth factor I), are un efect determinant asupra vârfului de densitate osoasă atins la mijlocul anilor douăzeci, în perioada de adult tânăr (1). Ritmul ultradian al eliberării GH- ului face dificilă identificarea cu precizie şi exactitate a deficitului somatotrop (2). Concentrațiile serice ale IGF1 şi markerilor de colagen cresc ca răspuns la $\mathrm{GH}(3,4)$.

În ciuda utilizării răspândite în anumite circumstanțe clinice a IGF 1 ca un test de screening pentru deficitul de GH (GHD), coeficientul său de reproductibilitate este mai mic decât cel al markerilor de colagen la determinări spaţiate în cazul aceluiaşi individ (5) (IGF binding protein 3 - IGFBP-3). Markerii de colagen nu sunt considerați instrument de diagnostic pentru GHD (6). Markerii surogat ai 
sintezei de colagen permit evaluarea formării osoase $(7,8)$.

Propeptidul amino-terminal al procolagenului tip I este derivat din colagenul de tip I - într-o manieră stoechiometrică şi este considerat o metodă de cuantificare a colagenului tip I nou format, colagenul principal al osului.

În timpul creşterii din copilărie, markerii surogat de formare osoasă circulă la concentrații mai mari decât în viaţa adultă şi se corelează cu viteza de înălţare $(9,10)$. Nivelurile lor variază în timpul pubertăţii şi sunt mai mari în perioadele de viteză maximă de creştere. GH-ul, precum şi hormonii sexuali influențează nivelurile markerilor de formare osoasă (11). GHD pare să aibă un efect semnificativ asupra ratei de reînnoire a colagenului în timpul copilăriei şi mai puțin în timpul maturităţii, atunci când hormonii sexuali şi factorii locali contracarează parțial consecințele negative ale deficitului cronic de GH-IGF-I în sinteza colagenului (12). Nu există date disponibile despre markerii surogat ai turnover-ului osos şi asocierea acestora cu statutul de GH în perioada de tranziţie.

Pentru a obține o aprofundare a rolului P1NP în screening-ul persistenței GHD în perioada de tranziție, am evaluat concentrațiile acestuia la adolescenţi GHD şi voluntari sănătoşi şi le-am comparat cu nivelurile IGF1. Am emis ipoteza că P1NP este mai scăzut la pacienții cu persistența GHD în perioada de tranziție.

\section{METODA}

\section{Subiecți}

Am evaluat P1NP într-un studiu de tip transversal. 17 pacienți de sex masculin diagnosticați în timpul copilăriei cu GHD, izolat (CO-IGHD), sau ca parte a deficitului multiplu hipofizar (MPHD) (4 pacienți), urmăriți în cadrul Departamentului de Pediatrie al Institutului Național de Endocrinologie, au fost selectaţi pentru acest studiu. O parte din prezentul grup a fost utilizat într-un studiu anterior în care am determinat persistența GHD în perioada lor de tranziție.

Toți pacienții au avut indicaţia de întrerupere a tratamentului cu GH pentru atingerea înălțimii finale în perioada cuprinsă între septembrie 2008 şi decembrie 2013.

Pacienții cu CO-IGHD au fost retestaţi pentru persistența GHD în perioada lor de tranziţie folosind testul de hipoglicemie insulin-indusă (ITT), cu nivel prag al GH-ului maxim stimulat de $6.1 \mathrm{ng} / \mathrm{dl}$. În urma ITT, 4 dintre cei 13 pacienți cu CO-IGHD au fost considerați ca GHD persistenţi şi împreună cu pacienții MPHD au fost incluşi în grupul pGHD (date nepublicate). Un grup de control de 8 subiecți sănătoşi, potriviți pentru vârstă şi etapă pubertară, au fost recrutați dintre copiii personalului medical al institutului nostru. Grupul de subiecți GH suficienți (sGH) a inclus subiecți cu GHD reversibil şi subiecții control.

Studiul a fost aprobat de comisia ştiinţifică a Departamentului de Pediatrie. Consimțământul informat scris a fost obținut de la toți părinții şi pacienții.

\section{Analizele biochimice}

Probele pentru determinarea IGF1 şi P1NP au fost colectate între orele 8 şi 9 dimineața, pe nemâncate. În următoarele 2 ore, probele au fost centrifugate la $4^{\circ} \mathrm{C}$, plasma separată şi utilizată pentru măsurători sau stocată la $-20^{\circ} \mathrm{C}$ până la analiza ulterioară.

IGF-1 a fost măsurat prin metoda chemiluminiscentă utilizând anticorpi monoclonali (Liaison, DIASORIN) (limita de detecție de $0,01 \mathrm{ng} / \mathrm{ml}$, coeficient de variație (CV) interdozare 8,2\%). P1NP total a fost analizat folosind anticorpi monoclonali de şoarece împotriva PINP prin metodă electrochemiluminiscentă cu un analizor Cobas (Elecsys 2010 total P1NP, Roche Diagnostics- limita de detecție $5 \mathrm{ng} / \mathrm{ml}, \mathrm{CV}$ interdozare 4,1\%).

În cazul P1NP, toate probele din studiu au fost măsurate folosind acelaşi lot de analiză.

\section{Valorile de referință}

Pentru IGF-1 şi P1NP, am calculat mediile specifice vârstei, deviaţia standard (DS) şi intervalele de încredere 95\% (95\% CI), folosindu-se valorile lor în grupul sGH. Pentru fiecare dintre cei doi parametri, am evaluat modificări cu vârsta, folosind un model de regresie polinomială (software statistic MedCalc v.14.8.1.0). Un al doilea model de regresie a fost folosit pentru a obține deviaţia standard în funcție de vârstă. Am stratificat grupul sGH în 2 intervale de vârstă (15-16,9 şi respectiv 17-19 ani), în conformitate cu specificaţiile din literatură pentru variația valorilor P1NP în funcție de vârstă. Pentru a verifica valorile aberante în fiecare grupă de vârstă, am folosit testul Tukey. Am evaluat normalitatea distribuției folosind testul Shapiro-Wilk pentru fiecare grupă de vârstă. Am evaluat omogenitatea varianțelor folosind testul Levene. Am calculat indicii de asimetrie şi aplatizare pentru fiecare grupă de vârstă. Am transformat în scor de deviație standard (SDS), folosind formula: $x$-media $x$ / DS, 
unde $x$ este valoarea absolută IGF-1 sau P1NP a pacientului, media $\mathrm{x}$ este media IGF1 sau P1NP pentru subgrupul de pacienți sGH din care face parte cazul index.

\section{Metoda prelucare date statistice}

Analiza statistică a fost realizată cu ajutorul SPSS v 16.0. Corelația dintre diferiți parametri a fost realizată folosind coeficientul Pearson (pentru date parametrice). Semnificația statistică a diferențelor între valorile medii între diferitele categorii a fost determinată folosind testul $\mathrm{t}$ (atunci când se compară două grupuri). O valoare $p 0.05$ a fost considerată semnificativă din punct de vedere statistic. Pentru a evalua performanța de diagnostic a IGF1 şi P1NP în caracterizarea GHD în perioada de tranziție, am ales nivelul prag al acestor parametri cu cea mai bună specificitate şi sensibilitate aşa cum a rezultat din analiza curbei ROC. Am folosit software-ul de statistică MedCalc v.14.8.1.0 pentru a compara performanța ariei de sub curba ROC (AUC) pentru cei doi parametri şi a identifica în mod corect starea de deficit de $\mathrm{GH}$.

\section{Rezultate obținute}

Am evaluat şaptesprezece pacienți de sex masculin cu GHD (4 MPHD), cu o vârstă medie de 17,3 ani, tratați în timpul copilăriei cu $\mathrm{GH}$ recombinant pentru o perioadă medie de 6,88 ani (interval 2,9-12,4 ani), după o perioadă minimă de 3 luni de la întreruperea tratamentului cu GH. Patru pacienți IGHD au menținut GHD după retestarea în perioada de tranziție. Un grup de 8 subiecți control, potriviți de vârstă, alături de pacienții cu GHD reversibil, au reprezentat grupul de subiecți cu axa GH competentă (sGH).

Tabelul 1 prezintă caracteristicile clinice şi biochimice ale subiecților separați în funcție de statu- sul axei GH. Toți subiecții au prezentat pubertate spontană în stadiul Tanner V de sexualizare sau au avut substituție adecvată cu steroizi sexuali.

Am stratificat grupul sGH în 2 intervale de vârstă (15-16.9 şi respectiv 17-19 ani). Valorile IGF1 şi P1NP au avut o distribuţie normală în grupul sGH aşa cum rezultă din testul Shapiro-Wilk (p> $0,05)$, cu un indice de asimetrie de 0,835 (eroare standard (SE) 0,550) şi un indice de aplatizare de $0.557(\mathrm{SE}=1,063)$ pentru IGF1 şi respectiv indice de asimetrie de $0,003(\mathrm{SE}=0,550)$ şi un indice de aplatizare de $-0.459(\mathrm{SE}=1,063)$ pentru P1NP. Valorile IGF1 şi P1NP mențin distribuția normală în grupurile stratificate în funcție de vârstă (datele nu sunt prezentate). Am folosit grupul sGH ca referință pentru valorile normale IGF1 şi P1NP. Am obținut pentru fiecare an de vârstă, media şi deviaţia standard (DS) pentru P1NP şi IGF-1 ca o funcție a vârstei. Vârsta a fost un predictor semnificativ doar pentru DS a P1NP. Am găsit o distribuție normală pentru P1NP şi IGF1 în grupul GHD stratificat în funcție de vârstă. Am găsit o suprapunere a valorilor absolute ale P1NP între pacienţi GHD şi grupul de referință. A existat o tendință către o diferență semnificativă a concentrațiilor absolute ale P1NP când comparăm cele două grupuri $(p=0,07)$, cu valori mai mici în grupul $\mathrm{GH}$ deficient. Pacienții GH suficienți au P1NP exprimat ca SDS (medie $=0$, $\mathrm{SE}=0,23)$ superior comparativ cu pacienții GHD (medie $=-0,71, \mathrm{SE}=0,58)$. Această diferență a fost semnificativă $[\mathrm{t}(21)=2,24, \mathrm{p}<0,05]$ şi reprezintă un efect mediu $r=0,44$. În grupul GH deficient nu a existat nici o valore a P1NP sub - 2SDS.

Deşi nu am găsit o diferență semnificativă între mediile pentru cei doi parametri, P1NP şi IGF1, când am comparat grupul sub 17 ani cu grupul de vârstă mai mare, am păstrat intervalele de referință

TABELUL 1. Caracteristicile pacienților separați în funcție de statusul GH

\begin{tabular}{|l|c|c|c|c|}
\hline & \multicolumn{2}{|c|}{ pGHD (n=8) } & \multicolumn{2}{c|}{ sGH (17) } \\
\hline BMI (SDS) & $0,40 \pm 1,82$ & {$[-2.9,1.4]$} & $-0,74 \pm 0,82$ & {$[-1.7,0.75]$} \\
\hline Ht (SDS) & $-1,1 \pm 1,12$ & {$[-3.2,0.09]$} & $-0,63 \pm 1,20$ & {$[-2.89,1.46]$} \\
\hline CA (ani) & $17,53 \pm 1,26$ & {$[15.2,18.9]$} & $16,94 \pm 1,01$ & {$[14.9,18.5]$} \\
\hline P1NP (SDS) & $-0,71 \pm 0,58$ & {$[-1.49,0.27]$} & $0 \pm 0,97$ & {$[-1.56,1.37]$} \\
\hline P1NP (ng/mL) & $214,36 \pm 74,57$ & {$[106.7,321.1]$} & $308,41 \pm 130,95$ & {$[120.2,537.8]$} \\
\hline IGF1 (SDS) & $2,1 \pm 1,48$ & {$[-3.69,0.49]$} & $0 \pm 0,97$ & {$[-1.46,2.04]$} \\
\hline IGF1 (ng/mL) & $209,68 \pm 151,88$ & {$[60.94,493.7]$} & $398,12 \pm 102,45$ & {$[250.8,638.8]$} \\
\hline timeTx (ani) & $1,38 \pm 1,27$ & {$[0.3,4.2]$} & $0,81 \pm 0,53$ & {$[0.3,1.9]^{*}$} \\
\hline
\end{tabular}

medie \pm SD [min, max]

pGHD, deficit persistent al GH; sGH, GH suficient; IMC, indice de masă corporală; SDS, scor deviație standard; Ht, înălțime; CA, vârsta cronologică; P1NP, capătul amino-terminal al procolagenului de tip I; IGF1, factor de creștere similar insulinei I; timeTX, timp de la întreruperea tratamentului cu GH;

* cu excepția subiecților control 
stratificate pe vârstă datorită diferenței semnificative dintre DS.

Figura 1 prezintă relația grafică dintre valoarea absolută a P1NP şi IGF-1, folosind o diagramă de dispersie. Am găsit o corelaţie pozitivă puternică între P1NP şi IGF-1, atât în grupul GHD, cât şi în grupul sGH ( $r=0,72$, CI [0,02 la 0,94], $p=0,046$ şi respectiv $\mathrm{r}=0,48 \mathrm{CI}[-0,01$ la 0,79$], \mathrm{p}=0,058)$.

După ce am ajustat pentru vârsta cronologică, deficitul de înălțime şi greutate, această corelație a fost menținută doar în grupul GHD. Tabelul 2 prezintă corelația între P1NP şi IGF1 şi anumiți parametri clinici.

Valorile $P$ semnificative sunt cu caractere îngroşate.

Analiza curbei ROC a arătat că cea mai bună valoare prag pentru IGF-1-SDS care discriminează între GHD şi sGH a fost -1,34 SDS, cu o sensibilitate de $80 \%$ CI $[44,4$ la 97,5$]$, o specificitate de $93,75 \%$ CI $[69,8$ la 99,8] şi AUC $=0,875$ CI $[0,686$ la 0,971$], p<0.05$. Probabilitatea prezisă pentru un rezultat pozitiv al testului $(\mathrm{LR}+)$ a fost de $12,8 \mathrm{CI}$ [1,9 la 87,6]. Probabilitatea prezisă pentru un rezultat negativ (LR-) a fost de $0,21 \mathrm{CI}[0,06$ la 0,7$]$.
Analiza curbei ROC a arătat că cea mai bună valoare prag pentru P1NP-SDS care discriminează între GHD şi sGH a fost $-0,66$ SDS, sensibilitate de $62,5 \%$ CI [24,5 la 91,5], specificitate de $75 \%$ CI [47,6 la 92,7] şi AUC $=0,719$ CI $[0,5$ la 0,881], $\mathrm{p}<0,05$. Probabilitatea prezisă pentru un rezultat pozitiv al testului $(\mathrm{LR}+$ ) a fost de 2,5 CI [0,9 la $6,8]$. Probabilitatea prezisă pentru un rezultat negativ al testului (LR-) a fost de 0,5 CI [0,2 la 1,3]. Nu am găsit o diferență semnificativă atunci când am comparat AUC pentru cei doi parametri $(\mathrm{p}=0,29)$.

\section{DISCUṬII}

P1NP este un marker al formării osoase. Acesta provine din conversia procolagenului în colagen în cursul sintezei de colagen tip I. Eliminarea capătului amino-terminal este realizată de proteaze specifice atunci când colagenul de tip I este încorporat în matricea osoasă. Concentrația P1NP este legată de cantitatea de os nou format (13). În 2011, Fundația Internaţională de Osteoporoză, Federația Internațională de Chimie Clinică şi Grupul de lucru privind standardele de Laborator ale markerilor osoşi au

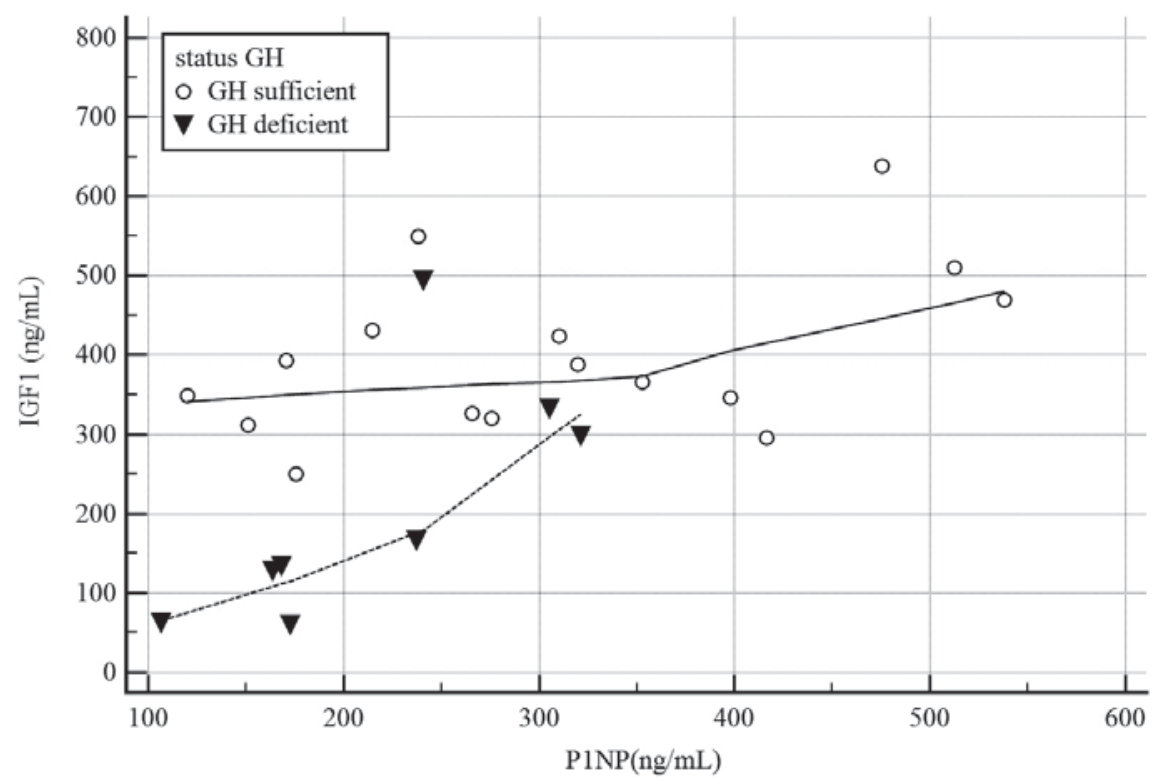

FIGURE 1. Corelația între propeptid amino-terminal colagen tip I, P1NP cu factorul de creştere similar insulinei

TABELUL 2. Corelația P1NP şi IGF1 cu parametri clinici

\begin{tabular}{|l|c|c|c|c|}
\hline & \multicolumn{2}{|c|}{ P1NP } & \multicolumn{2}{c|}{ IGF1 } \\
\hline & $r$ & $\mathbf{p}$ & $r$ & $p$ \\
\hline Ht (SDS) & 0,424 & $\mathbf{0 , 0 3 9}$ & 0,338 & 0,098 \\
\hline Greutate (kg) & $-0,139$ & 0,584 & $-0,560$ & $\mathbf{0 , 0 1 6}$ \\
\hline CA (ani) & $-0,383$ & 0,065 & $-0,593$ & $\mathbf{0 , 0 0 2}$ \\
\hline timeTx (ani) & $-0,393$ & 0,107 & $-0,476$ & $\mathbf{0 , 0 4 6}$ \\
\hline
\end{tabular}

$\mathrm{r}$ - coeficientul de corelație Pearson; P1NP - propeptidul amino-terminal al procolagenului de tip I; IGF1 - factorul de creștere similar insulinei I; SDS - scor deviație standard; Ht, înălțime; CA - vârsta cronologică; timeTX - timpul de la întreruperea tratamentului cu hormon de creștere 
recomandat utilizarea P1NP ca marker de referință pentru formarea osoasă (14).

Datele obținute în studiul nostru arată că în timpul perioadei de tranziție, P1NP se corelează pozitiv cu IGF-1. Studiile anterioare au arătat că lipsa efectului GH/IGF-I asupra turnover-ului osos, aşa cum apare în deficitul de hormon de creştere, este asociată cu formarea osoasă şi sinteza scăzută de colagen doar în timpul copilăriei, dar nu şi în viaţa de adult (12).

Nivelurile serice scăzute ale propeptidelor de procolagen în cazul copiilor cu GHD au fost legate de viteza de creştere redusă $(15,16)$.

Subiecții incluşi în studiul nostru sunt evaluaţi după atingerea înălțimii finale, în etapa de tineri adulți, într-o perioadă când acreția de masă mineral-osoasă continuă.

Am folosit pentru analiza biochimică un test pentru P1NP total care detectează două forme antigenice diferite ale P1NP, cea trimerică, intactă şi cea monomerică. Această caracteristică este relevantă în special atunci când modificările ce urmează să fie măsurate sunt relativ mici şi ar fi de aşteptat un comportament mai dinamic pentru un test care detectează P1NP intact (13). Concentrațiile plasmatice ale P1NP la pacienții GHD au fost în intervalul de referință pentru indivizi normali. Acest lucru poate fi explicat prin intervale de referință prea extinse ale acestui marker, cu variație inter-individuală considerabilă, reflectând mari variații inter-individuale ale ratei de înnoire osoasă la adulți (17).
Valorile P1NP variază în funcție de vârstă. În cazul subiecților noştri, corelația negativă a P1NP cu vârsta este de aşteptat, dat fiind declinul fiziologic al markerilor de colagen după parcurgerea pubertății (18). Spre deosebire de impactul negativ asupra valorilor IGF1, P1NP nu este influențat de greutate.

Valori similare pentru P1NP între pacienții cu GHD reversibil şi martori sugerează o rată a formării de masă osoasă normală în primul caz.

Am găsit o diferență semnificativă între P1NP, exprimat ca SDS între pacienții cu GHD şi subiecții GH-suficienți.

Acest fapt sugerează un rol determinant asupra markerilor turnover-ului osos al axei GH-IGF1 în timpul etapei de tranziţie, spre deosebire de viaţa de adult când steroizii sexuali au efectul principal (12). Am calculat AUC pentru P1NP şi am găsit putere de predicție pentru GHD similară cu cea a IGF1. Markerii de colagen au variabilitate intra-individuală mai mică în comparație cu IGF1 (5).

\section{CONCLUZII}

Un marker seric cu coeficient de reproductibilitate crescut este preferabil de utilizat atunci când se cuantifică beneficiul în timpul tratamentului.

În perioada de tranziție, atunci când viteza de creştere nu mai este disponibilă, dinamica P1NP, un marker de formare osoasă responsiv la $\mathrm{GH}$, ar putea fi utilă în cuantificarea eficienței tratamentului substitutiv cu GH. 